\title{
Hepatozoon species (Adeleorina: Hepatozoidae) of African bufonids, with morphological description and molecular diagnosis of Hepatozoon ixoxo sp. nov. parasitising three Amietophrynus species (Anura: Bufonidae)
}

\author{
Edward C Netherlands*, Courtney A Cook and Nico J Smit
}

\begin{abstract}
Background: Haemogregarines comprise a large group of apicomplexan blood parasites. In 1996 all anuran haemogregarines still in the genus Haemogregarina Danilewsky, 1885 were reassigned to the genus Hepatozoon Miller, 1908. Most (11/15, 73\%) African anuran Hepatozoon species have been recorded from the family Bufonidae, however, all these are recorded from only two host species, Amietophrynus mauritanicus (Schlegel, 1841) and Amietophrynus regularis (Reuss, 1833) from Northern and central Africa. To the authors' knowledge the only description of an anuran haemogregarine from South Africa is Hepatozoon theileri (Laveran, 1905), parasitising Amietia quecketti (Boulenger, 1895).

Methods: Thin blood smears for morphometrics and whole blood for molecular work, were collected from 32 Amietophrynus garmani (Meek, 1897), 12 Amietophrynus gutturalis (Power, 1927), and nine Amietophrynus maculatus (Hallowell, 1854), in Ndumo Game Reserve and Kwa Nyamazane Conservancy, KwaZulu-Natal, South Africa. Smears were Giemsa-stained, screened for haemogregarines, parasite stages measured, compared to each other and to other described African bufonid haemogregarines. Parasite $18 \mathrm{~S}$ rDNA was amplified using two apicomplexan-specific primer sets, HepF300/HepR900 and 4558/2733. Resulting sequences of the haemogregarine isolates from the three Amietophrynus species were compared with each other and to comparative haemogregarine sequences selected from GenBank.

Results: Morphological characteristics of parasite stages, in particular characteristically capped mature gamont stages, and molecular findings, supported all three haemogregarine isolates from all three Amietophrynus species to be the same, a species of Hepatozoon, and furthermore different morphologically from other previously recorded bufonid Hepatozoon species. The haemogregarine fell within a clade comprising other anuran Hepatozoon species and furthermore, within a monophyletic sub-clade along with $\mathrm{H}$. theileri and are described as Hepatozoon ixoxo sp. nov.

(Continued on next page)
\end{abstract}

\footnotetext{
* Correspondence: ec.netherlands@gmail.com

Unit for Environmental Sciences and Management, North-West University,

Potchefstroom, South Africa
} 
(Continued from previous page)

Conclusions: This is the first morphological and molecular account of Hepatozoon species within the family Bufonidae from South Africa, a study hoped to encourage the redescription and molecular analysis of those Hepatozoon species described in the past from Amietophrynus species, as well as to promote the use of both morphological and molecular characteristics in Hepatozoon species descriptions. This will aid in comprehensive Hepatozoon descriptions, which along with the use of phylogenetic analysis will give a better indication of these parasites possible vectors and life cycle dynamics.

Keywords: Adeleorid taxonomy, Apicomplexan phylogenetics, Frog blood haematozoan, Haemogregarine, South Africa, Toad

\section{Background}

Haemogregarines comprise a large group of apicomplexan blood parasites recorded from a wide range of tetrapod vertebrates and haematophagous invertebrates [1,2]. Haemogregarines are heteroxenous parasites and the group presently includes three families, namely the Haemogregarinidae Léger, 1911, Hepatozoidae Wenyon, 1926, and Karyolysidae Wenyon, 1926. Within these families there are six genera of blood parasites, differentiated on the sporogonic development in their invertebrate hosts $[3,4]$. Prior to the clarification of the haemogregarine life cycles in anuran hosts by Desser et al. [5], most were placed in the genus Haemogregarina Danilewsky, 1885. However in 1996, with further insight into the above, Smith [1] suggested that these haemogregarines were better suited to the genus Hepatozoon Miller, 1908 and thus transferred them accordingly. As a result, Hemolivia Petit, Landau, Baccam and Lainson, 1990 and Hepatozoon are the only two haemogregarine genera with species known to parasitise anuran hosts [2], with the latter currently representing the most common intraerythrocytic protozoan parasites of anurans worldwide [1].

According to Netherlands et al. [6], the majority (11/15, $73 \%$ ) of African anuran Hepatozoon species have been recorded from the family Bufonidae. Nine of the 11 (81\%) species, namely $H$. aegyptia (Mohammed and Mansour, 1963), $H$. assiuticus (Abdel-Rahman, El-Naffar, Sakla and Khalifa, 1978), H. boueti (França, 1925), H. faiyumensis (Mansour and Mohammed, 1966), H. francai (Abdel-Rahman, ElNaffar, Sakla and Khalifa, 1978), H. froilanoi (França, 1925), H. lavieri (Tuzet and Grjebine, 1957), H. magni (Hassan, 1992), and $H$. pestanae (França, 1910) [1], were recorded from the same vertebrate host Amietophrynus regularis (Reuss, 1833) in Egypt, Sudan, Nigeria, Guinea-Bissau, the Congo, and from northern Angola [7-16] (see Figure 1). The remaining two species, $H$. tunisiensis (Nicolle, 1904) described from Amietophrynus mauritanicus (Schlegel, 1841), and H. moloensis (Hoare, 1920) described from an unidentified species (likely $A$. regularis), were reported from Tunisia and Kenya respectively [17,18] (Figure 1) (Table 1). These species descriptions range from 20 to more than 100 years ago and were entirely morphology-based. Furthermore, illustrations and measurements were not standardised and therefore inconsistent, and deposited voucher specimens were not mentioned in any of the descriptions and reports. With so many species described from the same host in largely the same area, the huge diversity of Hepatozoon species from the above two hosts may in fact be a false representation of what may truly exist.

The aim of this study was therefor to elucidate, via traditional morphological description of peripheral blood stages and molecular techniques, the identity of the Hepatozoon species found to infect three Amietophrynus species from South Africa and to determine whether they represent a single species or three cryptic species, such as what has been recorded, solely morphologically, from other Amietophrynus species further north in Africa. According to the authors' knowledge the only record of an anuran haemogregarine from South Africa is Hepatozoon theileri (Laveran, 1905), described from the host Amietia quecketti (Boulenger, 1895), family Pyxicephalidae [6]. This paper therefore presents the first morphological and molecular account of a Hepatozoon species parasitising members of the Bufonidae from South Africa, and establishes the phylogenetic basis for all other bufonid Hepatozoon species in Africa.

\section{Methods}

Map (Figure 1) was created through ArcGIS 10.1 [19] using spatial data downloaded from IUCN Red List of Threatened Species [20].

\section{Frog collection and husbandry}

Specimens of Amietophrynus garmani (Meek, 1897), Amietophrynus gutturalis (Power, 1927), and Amietophrynus maculatus (Hallowell, 1854) [21,22], were collected by hand at night in the Ndumo Game Reserve, North Eastern KwaZulu-Natal (KZN), South Africa, from a total of eight sites. These include three temporary

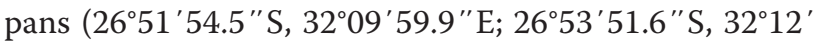
$57.2^{\prime \prime} \mathrm{E}$; and $26^{\circ} 52^{\prime} 53.5^{\prime \prime} \mathrm{S}, 32^{\circ} 15^{\prime} 03.4^{\prime \prime} \mathrm{E}$ ), one wetland $\left(26^{\circ} 54^{\prime} 08.2^{\prime \prime} \mathrm{S}, 32^{\circ} 14^{\prime} 15.0^{\prime \prime} \mathrm{E}\right)$, two riverine $\left(26^{\circ} 54^{\prime} 18.5^{\prime \prime} \mathrm{S}\right.$, $32^{\circ} 19^{\prime} 24.7^{\prime \prime} \mathrm{E}$; and $26^{\circ} 52^{\prime} 57.8^{\prime \prime} \mathrm{S}, 32^{\circ} 18^{\prime} 41.8^{\prime \prime} \mathrm{E}$ ), one lake $\left(26^{\circ} 53^{\prime} 35.6^{\prime \prime} \mathrm{S}, 32^{\circ} 17^{\prime} 45.2^{\prime \prime} \mathrm{E}\right)$, and one man-made pond at 


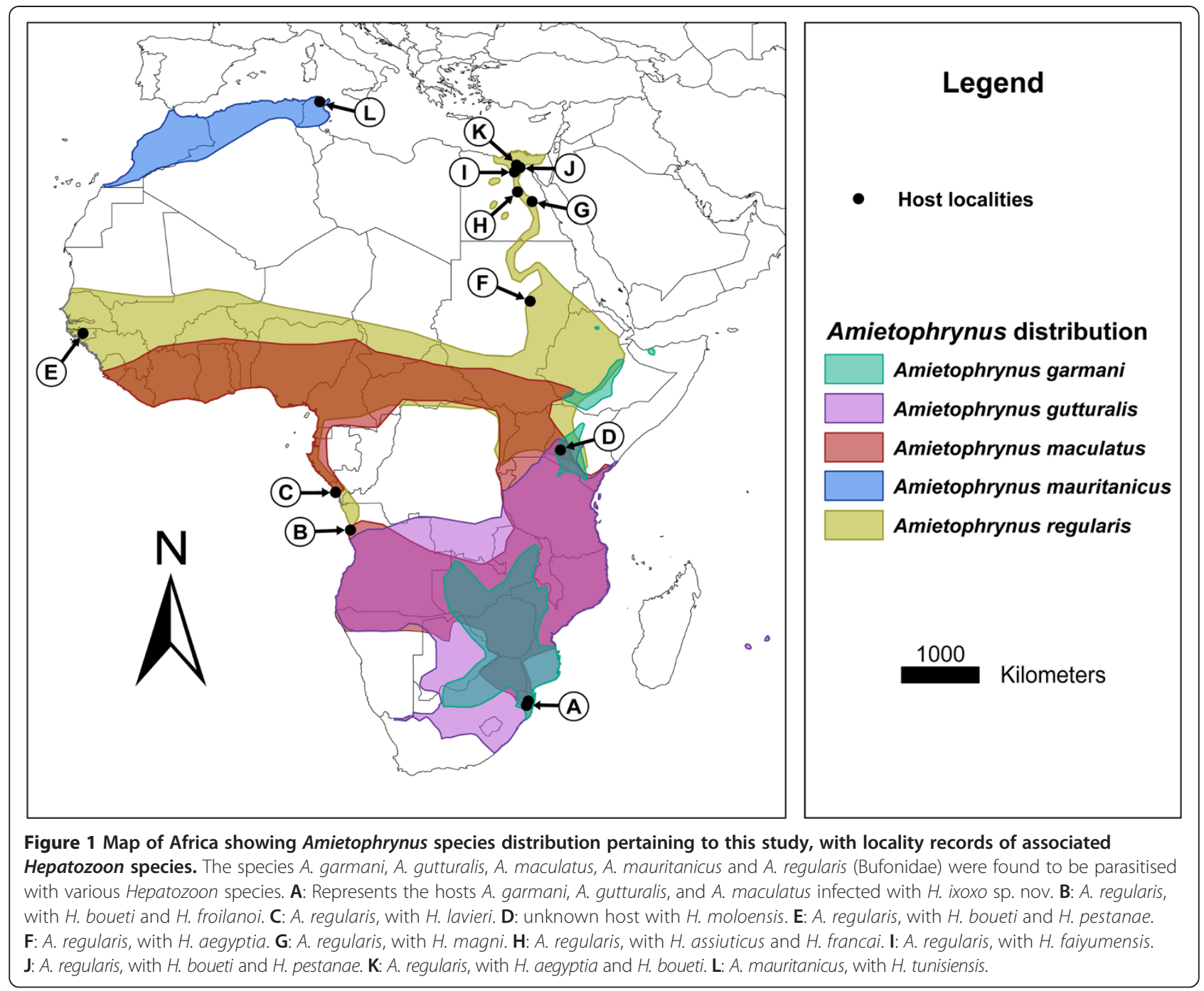

the campsite (26 $\left.54^{\prime} 33.8^{\prime \prime} \mathrm{S} ; 32^{\circ} 18^{\prime} 50.5^{\prime \prime} \mathrm{E}\right)$ (and therefore anthropogenically impacted); as well as from the Kwa Nyamazane Conservancy from a total of three sites, including two temporary pans $\left(27^{\circ} 23^{\prime} 43.9^{\prime \prime} \mathrm{S}, 32^{\circ} 08^{\prime} 33.7^{\prime \prime}\right.$ $\mathrm{E}$ and $27^{\circ} 24^{\prime} 35.1^{\prime \prime} \mathrm{S}, 32^{\circ} 08^{\prime} 47.8^{\prime \prime} \mathrm{E}$ ), and one riverine site $\left(27^{\circ} 23^{\prime} 26.5^{\prime \prime} \mathrm{S}, 32^{\circ} 08^{\prime} 24.2^{\prime \prime} \mathrm{E}\right)$. All these sites in KZN were visited during the warmer months of February and November 2012, April and November 2013 and February and April 2014. Two specimens, both A. maculatus, collected (26⒌'18.5"S, 32 $\left.{ }^{\circ} 19^{\prime} 24.7^{\prime \prime} \mathrm{E}\right)$ in April 2013, and found to be heavily parasitised with Hepatozoon species (3.8\% and $9.2 \%$ respectively), were kept, maintained in vivarium and fed on common garden crickets (Gryllus bimaculatus) for over a period of a year to monitor peripheral blood parasite stages and parasitemia on a bimonthly basis.

\section{Frog blood smear preparation and screening}

Blood was taken from the femoral arteries or veins and thin blood smears prepared, air-dried, fixed and stained using Giemsa-stain (FLUKA, Sigma-Aldrich, Steinheim,
Germany). Subsequently smears were screened at $100 \times$, images captured and parasites measured as described previously [6]. Parasitaemia was calculated per 100 erythrocytes, with $\sim 10^{4}$ erythrocytes examined per blood smear, following previous methods [23]. Descriptive statistics of the length (L) and width (W) results of mature gamont stages were compared between the three frog species using one way ANOVA (IBM SPSS V22). The remaining blood, that was not used in blood smear preparation, was placed in sterile $0.5 \mathrm{ml}$ reaction tubes with an equal volume of $70 \%$ molecular grade ethanol to be processed molecularly at a future date. This study received the relevant ethical approval (North-West University ethics approval no: NWU00005-14-S3).

\section{DNA extraction and phylogenetic analysis}

Peripheral blood, obtained from parasitised specimens of two A. garmani, two A. gutturalis, and four A. maculatus was transferred to sterile $0.5 \mathrm{ml}$ reaction tubes. Additionally 
Table 1 All described African Hepatozoon species infecting frogs from the family Bufonidae

\begin{tabular}{|c|c|c|c|c|}
\hline Hepatozoon species & Type and other hosts & Description mature gamont & Locality & References \\
\hline Hepatozoon ixoxo sp. nov. & $\begin{array}{l}\text { Amietophrynus maculatus (Hallowell, 1854); } \\
\text { Amietophrynus garmani (Meek, 1897); } \\
\text { Amietophrynus gutturalis (Power, 1927) }\end{array}$ & $\begin{array}{l}\text { Mature capped form: } 14.2 \pm 0.77 \\
(12.23-16.53) \times 7.5 \pm 0.51(6.0-8.5) \mu \mathrm{m} ; \\
3.9 \pm 1.20(2.6-5.9) \times 4.0 \pm 1.05(1.4-5.5) \mu \mathrm{m}\end{array}$ & $\begin{array}{l}\text { NGR and KNC } \\
\text { South Africa }\end{array}$ & Present study \\
\hline \multirow[t]{2}{*}{$\begin{array}{l}\text { Hepatozoon aegyptia (Mohammed } \\
\text { and Mansour, 1963) }\end{array}$} & \multirow[t]{2}{*}{$\begin{array}{l}\text { Amietophrynus regularis (Reuss, 1833) } \\
\text { (syn., Bufo regularis) }\end{array}$} & $\begin{array}{l}\text { Mature capped form }{ }^{\dagger}: 14 \times 7.3 \mu \mathrm{m} ; 3.7 \times \\
2.9 \mu \mathrm{m}\end{array}$ & Cairo, Egypt $^{\dagger}$ & Mohammed and Mansour [10]† \\
\hline & & $\begin{array}{l}\text { Mature capped form*: } 13.7(12.7-14.7) \times 8.1 \\
(6.7-8.6) \mu \mathrm{m} ; 3.9(3-4.5) \times 3.9(3.6-4.2) \mu \mathrm{m}\end{array}$ & Khartoum, Sudan* & Younis and Saoud [14]* \\
\hline $\begin{array}{l}\text { Hepatozoon assiuticus (Abdel-Rahman, } \\
\text { El-Naffar, Sakla and Khalifa, 1978) }\end{array}$ & Amietophrynus regularis & $\begin{array}{l}\text { Mature elongated form }{ }^{\dagger}: 35.4(30-38) \times 4.2 \\
(3.5-5) \mu \mathrm{m} ; 4.2(3-4.7) \times 4(2.8-4.6) \mu \mathrm{m}\end{array}$ & Assuit, Egypt ${ }^{\dagger}$ & Abdel-Rahman $[15]^{\dagger}$ \\
\hline \multirow{2}{*}{$\begin{array}{l}\text { Hepatozoon boueti (França, 1910) } \\
\text { [syn., Hepatozoon boneti França, } 1925 \\
\text { of Tuzet and Grjebine (1957)] }\end{array}$} & \multirow[t]{2}{*}{ Amietophrynus regularis } & $\begin{array}{l}\text { Mature elongated form }{ }^{\dagger}:(16.5-18.5) \times \\
4.5 \mu \mathrm{m} ; 4.5 \times(3-3.5) \mu \mathrm{m}\end{array}$ & Guinea-Bissau $^{\dagger}$ & França [7]† \\
\hline & & $\begin{array}{l}\text { Mature elongated form*: } 22.3(19-26) \times 6 \\
(5-6) \mu m ; 5.2(4-6) \times 4.2(3-6) \mu m\end{array}$ & Cairo and Giza, Egypt* & Mohammed and Mansour [11 $]^{*}$ \\
\hline $\begin{array}{l}\text { Hepatozoon faiyumensis (Mansour } \\
\text { and Mohammed, 1966) }\end{array}$ & Amietophrynus regularis & $\begin{array}{l}\text { Mature elongated form }{ }^{\dagger}: 15.5(13-17) \times 4.5 \\
(4-5) \mu \mathrm{m} ; 4.5(3-5) \times 3.9(3-5) \mu \mathrm{m}\end{array}$ & Faiyum, Egypt ${ }^{\dagger}$ & Mansour and Mohammed $[11]^{\dagger}$ \\
\hline $\begin{array}{l}\text { Hepatozoon francai (Abdel-Rahman, } \\
\text { El-Naffar, Sakla and khalifa, 1978) }\end{array}$ & Amietophrynus regularis & Mature capped form ${ }^{\dagger}:(18.5-20) \times(2.7-3) \mu \mathrm{m}$ & Assuit, Egypt $^{\dagger}$ & Abdel-Rahman et al. [15] $]^{\dagger}$ \\
\hline Hepatozoon froilanoi (França, 1925) & Amietophrynus regularis & $\begin{array}{l}\text { Mature elongated form }{ }^{\dagger}:(16.5-21) \times 4.5 \mu \mathrm{m} ; \\
(6-7.5) \times 4.5 \mu \mathrm{m}\end{array}$ & Luanda, Angola $^{+}$ & França $[8]^{\dagger}$ \\
\hline $\begin{array}{l}\text { Hepatozoon lavieri (Tuzet and } \\
\text { Grjebine, 1957) }\end{array}$ & Amietophrynus regularis & Possible gamont form ${ }^{\dagger}: 20 \mu \mathrm{m}$ in length & Pointe-Noire, Congo ${ }^{\dagger}$ & 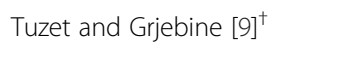 \\
\hline \multirow[t]{2}{*}{ Hepatozoon magni (Hassan, 1992) } & \multirow[t]{2}{*}{ Amietophrynus regularis } & $\begin{array}{l}\text { Capped form }+15.05(14.2-16.8) \times 7.7 \\
(6.3-9.8) \mu \mathrm{m} ; 3.4(2.8-4.2) \times 3.4(2.8-4.2) \mu \mathrm{m}\end{array}$ & \multirow[t]{2}{*}{ Qena, Egypt ${ }^{\dagger}$} & \multirow[t]{2}{*}{ Hassan $[16]^{\dagger}$} \\
\hline & & $\begin{array}{l}\text { Mature elongated form }{ }^{\dagger}: 22.5(21.2-26.6) \times 8.2 \\
(7.7-9.1) \mu \mathrm{m} ; 4.3(4.1-4.6) \times 4.5(4.3-4.8) \mu \mathrm{m}\end{array}$ & & \\
\hline Hepatozoon moloensis (Hoare,1920) & Amietophrynus spp. & Mature capped form ${ }^{\dagger}: 18.8 \times 7.8 \mu \mathrm{m}$ & Molo, Kenya $^{+}$ & Hoare $[18]^{\dagger}$ \\
\hline \multirow[t]{2}{*}{ Hepatozoon pestanae (França, 1910) } & \multirow[t]{2}{*}{ Amietophrynus regularis } & Mature capped form ${ }^{\dagger}: 12 \times 4.5 \mu \mathrm{m} ; 3.7 \mu \mathrm{m}$ & Guinea-Bissau $^{\dagger}$ & França [7]† \\
\hline & & $\begin{array}{l}\text { Mature capped form*: } 13(12-17) \times 5 \\
(4.5-5) \mu \mathrm{m} ; 4.2 \times 3.7 \mu \mathrm{m}\end{array}$ & Giza, Egypt* & Mohammed and Mansour [13]* \\
\hline Hepatozoon tunisiensis (Nicolle, 1904) & $\begin{array}{l}\text { Amietophrynus mauritanicus (Schlegel, } \\
\text { 1841) [syn., Bufo mauritanicus] }\end{array}$ & Mature capped form ${ }^{\dagger}(12-15) \times 8 \mu \mathrm{m}$ & Tunis, Tunisia $^{\dagger}$ & Nicolle $[17]^{\dagger}$ \\
\hline
\end{tabular}

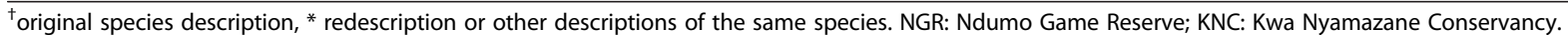

Measurements given where possible, length mean \pm standard deviation (range) $\times$ width mean \pm standard deviation (range); nucleus length mean \pm standard deviation (range) $\times$ nucleus width mean \pm standard deviation (range). 
the blood of one highly parasitised Amietia quecketti with Hepatozoon theileri from a previous study [6], was also used in order to obtain a longer sequence for comparison. DNA was extracted from the samples using the standard protocol for human or animal tissue and cultured cells as detailed in the NucleoSpin ${ }^{\circ}$ Tissue Genomic DNA Tissue Kit (Macherey-Nagel, Düren, Germany). To amplify apicomplexan parasite $18 \mathrm{~S}$ rDNA from the total DNA extracted, polymerase chain reaction (PCR) sequence runs were undertaken in a Bio-Rad C1000 Touch ${ }^{\mathrm{Tu}}$ Thermal Cycler (Bio-Rad, Hemel Hempstead, UK). PCR reactions were performed in volumes of $25 \mu \mathrm{l}$, using $12.5 \mu \mathrm{l}$ Thermo Scientific PCR master mix (2X) (0.05 U/ $\mu$ l Taq DNA Polymerase reaction buffer, $0.4 \mathrm{mM}$ of each dNTP, and $4 \mathrm{mM}$ $\mathrm{MgCl} 2), 1.25 \mu \mathrm{l}$ of each primer, and at least $25 \mathrm{ng}$ of DNA. The final reactions volume was made up of PCR grade nuclease free water (Thermo Scientific). Identification of Hepatozoon species were initially completed using the Hepatozoon specific SIGMA primer set HepF300: 5'-GTTTCTGACCTATCAGCTTTCGACG-3' and HepR900 5'-C AAATCTAAGAATTTCACCTCTG AC-3'. The PCR reactions were run targeting a fragment (approximately $600 \mathrm{bp}$ ) of the $18 \mathrm{~S}$ rDNA gene [24]. Conditions for PCR are detailed according to previous methods [6]. A second PCR was carried out using another apicomplexan-specific parasite SIGMA primer set 4558: 5'-GCTAATACATGAGCAAAATCTCAA-3' and 2733: 5'-CGGAATTAACCAGACAAAT-3' [25], targeting a longer fragment (approximately 1,120 bp) of the 18S rDNA gene for all samples found positive with Hepatozoon species. PCR conditions were as follows: initial denaturation at $94^{\circ} \mathrm{C}$ for $3 \mathrm{~min}$, followed by 40 cycles, entailing a $94^{\circ} \mathrm{C}$ denaturation for $1 \mathrm{~min}$, annealing at $55^{\circ} \mathrm{C}$ for $2 \mathrm{~min}$ with an end extension at $72^{\circ} \mathrm{C}$ for $2 \mathrm{~min}$, and following the cycles a final extension of $72^{\circ} \mathrm{C}$ for $10 \mathrm{~min}$ [25]. Resulting amplicons were visualised under UV on a $1 \%$ agarose gel stained with gel red using a Bio-Rad GelDoc Imaging System (Bio-Rad, Hemel Hempstead, UK). PCR products were sent to a commercial sequencing company (Inqaba Biotechnical Industries (Pty) Ltd. Pretoria, South Africa) for purification and sequencing in both directions.

From the resulting sequences chromatogram-based contigs were generated and trimmed using Geneious Ver. 7.1 [26], for further analysis. All the sequences have been uploaded onto GenBank under the accession numbers [GenBank: KP119770 - KP119773].

Sequences were identified as those of Hepatozoon using the Basic Local Alignment Search Tool (BLAST) [27], and comparative haemogregarine sequences were selected for further phylogenetic analysis. In addition to the four sequences obtained from the three Amietophrynus species and one $A$. quecketti in this study, 18 additional sequences were acquired from GenBank, 15 Hepatozoon as well as a single Hemolivia [GenBank: KC512766], Haemogregarina [GenBank: KF257925] and Dactylosoma [GenBank: HQ224957] (used as an outgroup) species. All phylogenetic analyses were undertaken using the Geneious (Ver. 7.1) bioinformatics software package. Sequences were aligned using the MUSCLE algorithm [28], for both Maximum likelihood (ML) and Bayesian inference (BI) analyses. The alignment consisted of 22 taxa and 690 bp long. ML phylogeny was completed using PhyML Ver. 2.4.4 plugin [29], according to the estimated AIC criterion using jModelTest Ver. 2.1.5 [30]. The chosen parameters of the substitution model were TVM $+\mathrm{G}$. Nodal support was undertaken with 1000 Bootstrap replicates. Tree topology search was completed using Nearest Neighbour Interchange (NNI) and Subtree Pruning and Regrafting (SPR). BI phylogeny was implemented using MrBayes Ver. 3.2.1 plugin [31], under the estimated parameters as part of the analysis. The analysis was run twice for $2 \times 10^{6}$ generations; saving one tree every 1000 generations; with burn-in values of 100,000 and four chains at a temperature of 0.20 . The log-likelihood values of the sample point were plotted against the generation time and all the trees prior to reaching stationary were discarded, no burn-in samples were retained. Remaining trees were combined in a 50\% majority consensus tree, in which frequency of any particular clade represents the posterior probability [31]. Strict consensus trees for both ML and BI trees were generated and visualised using Tree-view [4].

\section{Results}

\section{General observations}

Three species from the family Bufonidae were sampled from the Ndumo Game Reserve and the Kwa Nyamazane Conservancy, KZN (A. garmani and A. maculatus, and A. gutturalis respectively). Of the 53 individuals collected 16 (30.1\%) were found to be infected with haemogregarines; from the Ndumo Game Reserve, 1/23 (4.3\%) from A. garmani and 6/9 (66.7\%) from A. maculatus; from the Kwa Nyamazane Conservancy, 5/9 (55.6\%) from $A$. garmani and 4/12 (33\%) from A. gutturalis. These infections were recorded from frogs inhabiting mainly riverine sites with the exception of two individuals from two separate temporary pans in the Kwa Nyamazane Conservancy. It was found that frogs collected from other sites such as the wetland, lake and campsite were not infected with the parasite. Five different stages were found in the peripheral blood. Trophozoite, meront and merozoite stages were rare and were only observed within the blood smears of two individuals of $A$. maculatus collected in April 2013 from the Ndumo Game Reserve. The most frequently encountered stages were immature and mature gamont stages, the latter stage being the most abundant across all the parasitised 
specimens. The mature gamont was characterised by a well-developed cap, typically staining pink, situated at one pole of a delicate capsule. According to the morphological measurements (Table 2) and other morphological features (as described in the detailed description) of the gamont stages, it is suggested that the Hepatozoon species found parasitizing all three toads is one of the same. This was concluded in spite of the size of the mature gamonts measured from A. garmani being smaller, with statistical differences considered to be significant at $\mathrm{p}<0.05$ compared to both A. gutturalis and A. maculatus $\mathrm{p}=0.000$. The latter two appeared to be very similar $\mathrm{p}=0.628$, with no significant difference observed. Pending the molecular outcome, this was attributed to intra-species variation. Throughout the collection of the host specimens no vectors were observed feeding on the frogs.

\section{Taxonomic summary}

Phylum Apicomplexa Levine, 1970.

Family Hepatozoidae Wenyon, 1926.

Genus Hepatozoon Miller, 1908.

Description of Hepatozoon ixoxo sp. nov. Netherlands, Cook, and Smit, 2014.

\section{Morphology}

Trophozoite: irregular to ovoid shape, often vacuolated cytoplasm, measuring $9.5 \pm 1.3(6.9-11.7)$ long by $3.3 \pm$ $0.7 \mu \mathrm{m}(2.2-4.8)$ wide $(\mathrm{n}=23)$, nucleus with loose chromatin, staining pink to purple, measuring $3.4 \pm 0.8 \mu \mathrm{m}$ (2-4.8) long by $2.2 \pm 0.5 \mu \mathrm{m}(1.5-43.8)$ wide (Figure $2 \mathrm{~A}$ ).

Meront: globular in shape, with a foamy cytoplasm, staining white, measuring $8.2 \pm 1.3 \mu \mathrm{m}$ (7-9.5) long by
$8.5 \pm 2 \mu \mathrm{m}(7.1-9.9)$ wide $(\mathrm{n}=3)$. The nucleus has loosely arranged chromatin, extending outwards, staining light pink, measuring $4.6 \pm 1.6 \mu \mathrm{m}$ (3.2-6.3) long by $5.1 \pm 1.4$ $\mu \mathrm{m}(3.5-5.9)$ wide $(\mathrm{n}=3)$ (Figure 2B, C). Possible latermeront stage, with granulated cytoplasm, staining light purple, with four distinct and condensed nuclei, staining dark purple (Figure 1C).

Merozoite: elongated in shape, tapering toward one pole (possibly anterior), rounded at the other (possibly posterior), found either free in between the erythrocytes (Figure 2D), or possibly entering or leaving an erythrocyte, vacuolated cytoplasm, staining light blue, measuring $12.9 \pm 1.9 \mu \mathrm{m}$ (10.7-14.4) long by $3.2 \pm 0.8 \mu \mathrm{m}$ (2.5-4) wide, nucleus staining similarly light blue with a condensed appearance, measuring $4.7 \pm 0.6 \mu \mathrm{m}$ (4-5.2) long by $3.1 \pm 0.8 \mu \mathrm{m}(2.5-4)$ wide $(\mathrm{n}=3)$.

Immature gamonts: oval shaped without cap or cavity at truncate pole (Figure 2F-G arrow-head), cytoplasm staining whitish-blue or purple, measuring $14.2 \pm 0.7 \mu \mathrm{m}$ (11.6-16) long by $6.4 \pm 0.6 \mu \mathrm{m}(4.4-7.9)$ wide $(\mathrm{n}=102)$. Irregular oval shaped nucleus, with loose chromatin, staining dark blue or purple, measuring $5 \pm 1.4 \mu \mathrm{m}$ (3.3-7.3) long by $3.9 \pm 0.8 \mu \mathrm{m}(1.9-6)$ wide. Infrequently a recurved tail was observed (Figure 2F arrow), the nucleus lying nearer to the anterior pole (the broader pole of the parasite) (Figure 2F).

Mature gamonts: oval shaped with a well-developed cap/cavity at the truncate pole (Figure 2H-I arrowhead) or folded region of the parasite, often staining pink (Figure 2H-L); seemingly encased by a thick parasitophorous vacuole or delicate capsule, gamont with cap measuring $14.2 \pm 0.8 \mu \mathrm{m}(12.2-16.5)$ long by $7.5 \pm 0.5 \mu \mathrm{m}$ (6-8.5) wide $(\mathrm{n}=133)$; excluding cap measuring $11.8 \pm$

Table 2 Morphometrics of Hepatozoon ixoxo sp. nov. from the Amietophrynus species collected in this study

\begin{tabular}{|c|c|c|c|}
\hline \multirow[t]{2}{*}{ Frog hosts by species } & \multicolumn{3}{|c|}{ Measurements of the different stages found in the different host species } \\
\hline & Trophozoites: & Immature gamonts: & Mature gamonts: \\
\hline \multirow[t]{2}{*}{$\begin{array}{l}\text { Amietophrynus garmani } \\
\text { (Meek, 1897) }\end{array}$} & & $\begin{array}{l}13.2 \pm 0.6(11.6-14.0) \times 5.7 \pm 0.3 \\
(5.0-6.2) \mu m\end{array}$ & $\begin{array}{l}13.8 \pm 0.7(12.2-15.5) \times 7.4 \pm 0.6 \\
(6.0-8.5) \mu \mathrm{m} ;\end{array}$ \\
\hline & & $\begin{array}{l}5.0 \pm 0.7(3.6-6.2) \times 4.1 \pm 0.6 \\
(2.6-5.1) \mu m(n=16)\end{array}$ & $\begin{array}{l}3.8 \pm 1.3(2.7-5.1) \times 3.5 \pm 1.2 \\
(1.4-4.7) \mu m(n=66)\end{array}$ \\
\hline \multirow[t]{2}{*}{$\begin{array}{l}\text { Amietophrynus gutturalis } \\
\text { (Power, 1927) }\end{array}$} & & $\begin{array}{l}14.7 \pm 0.5(13.7-16.0) \times 6.7 \pm 0.2 \\
(6.1-7.1) \mu m ;\end{array}$ & $\begin{array}{l}14.7 \pm 0.9(12.3-16.5) \times 7.6 \pm 0.3 \\
(7.1-8.2) \mu \mathrm{m} ;\end{array}$ \\
\hline & & $\begin{array}{l}4.9 \pm 0.7(3.7-6.9) \times 3.90 \pm 0.9 \\
(2.0-6.1) \mu m(n=26)\end{array}$ & $\begin{array}{l}4.1 \pm 1.1(3.2-5.3) \times 4.0 \pm 1.1 \\
(2.5-4.8) \mu m(n=20)\end{array}$ \\
\hline \multirow[t]{2}{*}{$\begin{array}{l}\text { Amietophrynus maculatus } \\
\text { (Hallowell, 1854) }\end{array}$} & $\begin{array}{l}9.5 \pm 1.3(6.9-11.7) \times 3.3 \pm 0.5 \\
(2.2-4.8) \mu m(n=23)\end{array}$ & $\begin{array}{l}14.4 \pm 0.4(13.6-15.3) \times 6.1 \pm 0.5 \\
(4.4-6.8) \mu m ;\end{array}$ & $\begin{array}{l}14.5 \pm 0.5(13.4-15.7) \times 7.6 \pm 0.4 \\
(6.6-8.5) \mu \mathrm{m} ;\end{array}$ \\
\hline & & $\begin{array}{l}5.2 \pm 0.6(4.3-6.3) \times 4.2 \pm 0.5 \\
(2.7-4.9) \mu m(n=26)\end{array}$ & $\begin{array}{l}3.9 \pm 0.5(3.0-5.1) \times 4.3 \pm 0.5 \\
(2.7-4.9) \mu m(n=46)\end{array}$ \\
\hline \multirow[t]{2}{*}{ Total average } & & $\begin{array}{l}14.2 \pm 0.7(11.6-16.0) \times 6.4 \pm 0.6 \\
(4.4-7.9) \mu m\end{array}$ & $\begin{array}{l}14.2 \pm 0.77(12.23-16.53) \times 7.5 \pm 0.51 \\
(6.0-8.5) \mu m ;\end{array}$ \\
\hline & & $\begin{array}{l}5.0 \pm 1.4(3.3-7.3) \times 3.9 \pm 0.8 \\
(1.9-6.1) \mu m(n=102)\end{array}$ & $\begin{array}{l}3.9 \pm 1.20(2.6-5.9) \times 4.0 \pm 1.05 \\
(1.4-5.5) \mu m(n=132)\end{array}$ \\
\hline
\end{tabular}




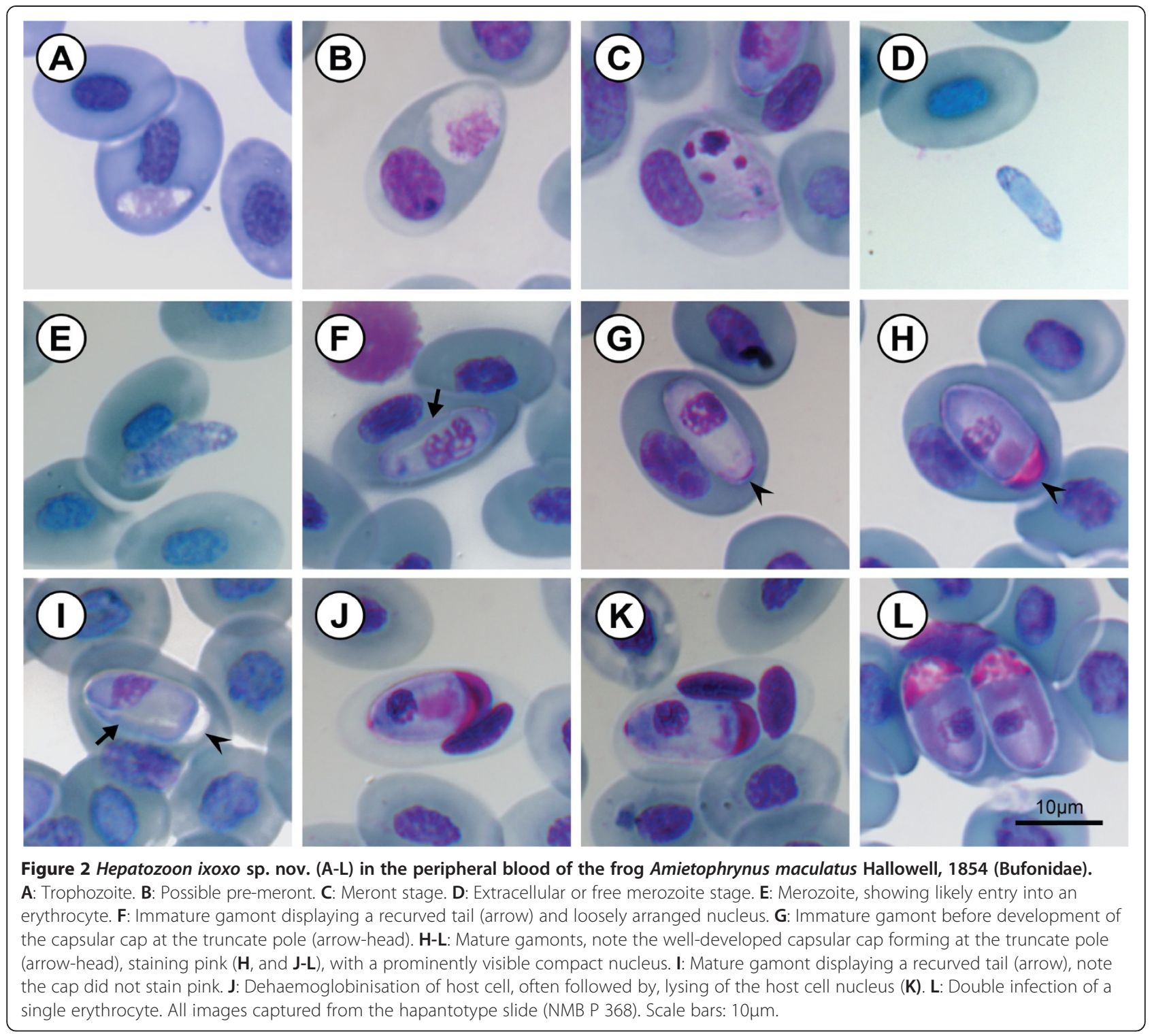

2.4 $\mu \mathrm{m}$ (8-14.3) long, width remaining the same. A small recurved tail seldom visible (Figure 2I arrow). Whitish-blue to purple staining cytoplasm, with an irregular, oval-shaped, blue or dark-purple staining nucleus measuring $3.90 \pm 1.20 \mu \mathrm{m}$ (2.6-5.9) long by $4 \pm 1.1 \mu \mathrm{m}$ (1.5-5.5) wide; in some cases the gamont would cause dehaemoglobinisation of the host cell (Figure 2J-K), as well as lysing of its nucleus (Figure 2K).

\section{Type host}

Amietophrynus maculatus (Hallowell, 1854), Anura: Bufonidae.

\section{Other hosts}

Amietophrynus garmani (Meek, 1897), and Amietophrynus gutturalis (Power, 1927), Anura: Bufonidae.

\section{Vector}

Unknown.

\section{Type locality}

The specimens were collected along the Phongolo River $\left(26^{\circ} 54^{\prime} 18.5^{\prime \prime} \mathrm{S}, 32^{\circ} 19^{\prime} 24.7^{\prime \prime} \mathrm{E}\right)$ in the Ndumo Game Reserve, KwaZulu-Natal, South Africa.

\section{Type material}

Hapantotype, $1 \times$ blood smear from Amietophrynus maculatus NMB P 368; parahapantotypes, $1 \times$ blood smear from Amietophrynus garmani NMB P 369 and Amietophrynus gutturalis NMB P 370 respectively, deposited in the Protozoan collection of the National Museum, Bloemfontein, South Africa. 


\section{General}

In accordance with section 8.5 of the ICZN's International Code of Zoological Nomenclature, details of the new species have been submitted to ZooBank with the life science identifier (LSID) zoobank.org:pub: 3DA4C6373508-4EC2-A7BC-253EDCD07CB1.

\section{Gene sequences}

The 18S ribosomal RNA gene sequences have been uploaded onto GenBank under the accession numbers [GenBank: KP119770 - KP119772].

\section{Etymology}

The species is named after the Zulu name for frog or toad, since the hosts consist of various frog species and the parasite species type locality is in KwaZulu-Natal. "Ixoxo" is correctly pronounced [i:\|T:Io] in which each ' $x$ ' is a single lateral click that is best approximated in Indo-European languages with a 'ch'. "Ixoxo" is pronounced "ee-ch-o-ch-o".

\section{Molecular analysis}

Once edited for phylogenetic analysis, four high-quality sequences of 1033 base pairs (bp), one from each of the three Amietophrynus species and one from an $A$. quecketti infected with $H$. theileri, were produced using 4558 and 2733 primer sets, targeting part of the $18 \mathrm{~S}$ rDNA gene [25]. The overall topology of the generated ML and BI phylogenetic trees were identical and nodal support of each analysis is represented on the ML tree as ML/BI (Figure 3). The phylogenetic tree comprises three distinct clades. The haemogregarine isolates of all three Amietophrynus species, as well as that of the A. quecketti, were found to fall within the first clade comprising mostly anuran Hepatozoon species. Furthermore, that from A. quecketti was found to be, as expected, identical to a previously deposited isolate of $H$. theileri [6]. The three isolates [GenBank: KP119770 - KP119772] from the Amietophrynus species were all found to be identical and to form a sister taxon to $H$. theileri [GenBank: KJ599676; KP119773] (see Figure 3).

\section{Bimonthly peripheral blood observations}

Two specimens of highly parasitised A. maculatus (collected in April 2013) were kept in a vivarium and their blood screened for peripheral blood stages on a bimonthly basis, from May 2013 to and including May 2014. This was done in order to monitor their parasitaemia levels in the absence of a vector, as well as to observe any changes in the peripheral blood stages. The parasitaemia over a period of one year for the first specimen averaged $4.8 \%(3.6-6.6 \%)$. May 2014 had the lowest parasitemia of $3.6 \%$ and July 2013 the highest of $6.6 \%$. The second specimen's parasitemia averaged
$12.5 \%$ (8.2-19.2\%). May 2014 had the lowest parasitemia of $8.2 \%$ and July 2013 the highest of $19.2 \%$. In both specimens, upon first collection (April 2013), trophozoite, merozoite, immature and mature gamont stages were observed. As the observation period progressed from there on, only immature and mature gamont stages were observed, mature gamont stages being the predominant stage. Parasitaemia levels peaked within the first four months (July 2013) and then steadily decreased over the next nine months to a similar parasitaemia level as was first recorded in May 2013. No extracellular or extracapsular gamonts were ever observed during this period in the peripheral blood.

\section{Discussion}

Morphological characteristics of peripheral blood parasite stages strongly suggested that all three Amietophrynus species were infected with the same species of haemogregarine, likely, based on the lack of peripheral division stages and the recommendations on anuran haemogregarines of Smith [1], a species of Hepatozoon. This was supported molecularly, with sequences of haemogregarine isolates from all three frog species being identical and falling within a clade comprising other anuran Hepatozoon species (see Figure 3).

The capped mature gamont form of the Hepatozoon described here was the most frequently encountered stage throughout the current study, as well as in several other studies of bufonid Hepatozoon, and is thus consequently considered further within the following discussion. In terms of morphometrics the capped mature gamonts of $H$. ixoxo sp. nov. are most similar to the capped forms of $H$. aegyptia, $H$. magni and $H$. tunisiensis (see Table 1). Even though the present study's capped gamont form shares a number of morphological similarities to all three of the above described parasites, it does not conform entirely to any of these three. All four parasites, including this study's Hepatozoon, are characterised by being tightly enclosed in a delicate capsule that does not appear to interfere with the staining of the parasite as do those of chelonians [23,32,33], and all show some form of a cap-like structure or space at one or both poles that is filled with a dark-staining intracapsular material (Figure 1H-L). In addition, all four species' gamonts appear to be folded-over on themselves forming two branches within the capsule, the nucleus of all four situated within the wider of the two branches. Of the four similar species, $H$. tunisiensis does not have a definite cap at the truncate end (the region of the fold) (Figure 1G-I, arrow-head) of the parasite, the intracapsular material scattered frequently around the gamont and accumulating towards the poles of the encapsulated parasite, forming, in comparison to the other three, weak cap-like structures. Similarly, the parasite described in 


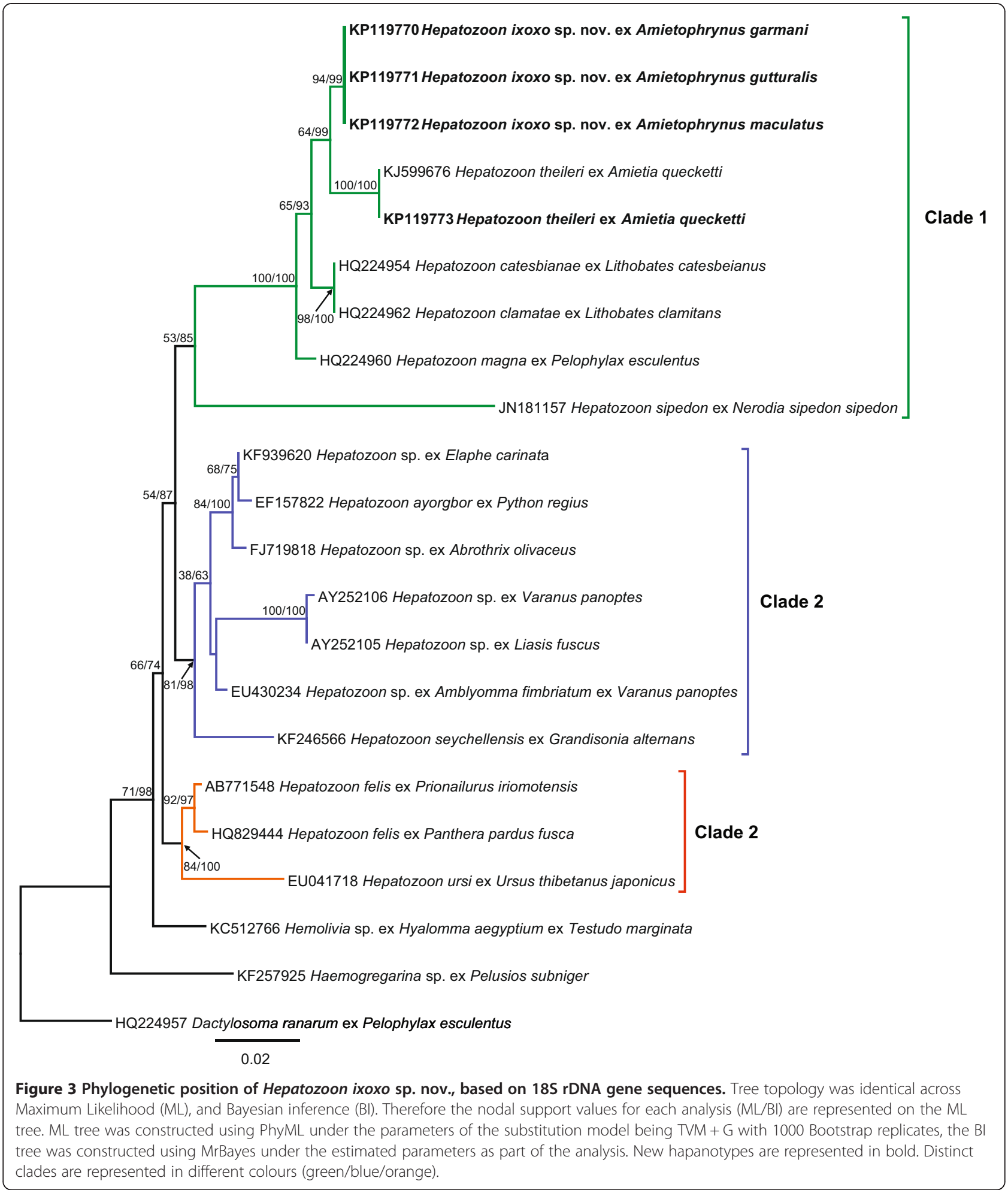

this study shows some scattered intracapsular material (Figure $1 \mathrm{H}, \mathrm{J}, \mathrm{K}$ ), but unlike $H$. tunisiensis it has a distinct cap similar to those of $H$. aegyptia and $H$. magni. Furthermore, Nicolle [19] described $H$. tunisiensis to cause no hypertrophy of the host cell, this being equally true of
H. magni described by Hassan [16], which is in direct contrast to $H$. aegyptia and $H$. ixoxo sp. nov., which both cause fragmentation of the host cell nucleus as well as dehaemoglobinisation of the host cell cytoplasm (see Figure 1J-K). Even though it would appear that 
H. ixoxo sp. nov. conforms closely both in size and morphological characteristics to $H$. aegyptia, during the period of a year in which peripheral blood stages were monitored bimonthly, no elongated forms, such as those of $H$. aegyptia and $H$. magni, were ever observed for $H$. ixoxo sp. nov.

Geographically, all three frog species examined in this study are sympatric. The finding that the haemogregarine isolates from these three frog species represents the same Hepatozoon species, $H$. ixoxo sp. nov., is thus not surprising. In addition, even though A. garmani, A. gutturalis and $A$. maculatus are sympatric to A. regularis, the closest geographical overlap to the present study's site is Kenya, which even though $A$. regularis has been examined there in the past no haemogregarine infections were ever reported [34]. Since the above frog species are found to occur sympatrically in Kenya, it would be expected that the same is true for their parasites, $H$. ixoxo sp. nov. and $H$. aegyptia respectively, as can be seen in the case of $H$. catesbianae and $H$. clamatae which along with their hosts occur sympatrically across Nova Scotia [35]. It may be that the Hepatozoon species of African bufonids are locality specific as are some of those infecting African chelonians [23,33,36], or the snakes of Florida in the U.S.A. [37]. As mentioned previously, H. ixoxo sp. nov., was found parasitising frogs inhabiting temporary pan and riverine sites as compared to no visible infections in frog hosts inhabiting wetland, lake and campsites. It may suggest that the infection is especially dependent on a vector that may be limited to a specific habitat. Hence, considering the above morphological and geographical aspects, it is strongly suggested that $H$. ixoxo sp. nov. is a new species.

Molecularly, as mentioned above, $H$. ixoxo sp. nov. fell within the first clade (represented in green) comprising anuran Hepatozoon species (Figure 3). The second clade (represented in blue) comprises mainly of reptile hosts with the exception of a Hepatozoon sp. [GenBank: FJ719818] from the rodent host Abrothrix olivaceus (Waterhouse, 1837) and surprisingly Hepatozoon seychellensis Harris, Damas-Moreira, Maia et Perera 2014 [GenBank: KF246566], from the caecilian host Grandisonia alternans (Stejneger, 1893) [38]. The third clade (represented in orange) comprises Hepatozoon spp. from larger mammal hosts and falls outside other Hepatozoon spp. from amphibian and reptile hosts.

The first clade, dominated by anuran Hepatozoon, comprises one exception, that of Hepatozoon sipedon Smith, Desser et Martin, 1994 [GenBank: JN181157], which is a Hepatozoon species of both an anuran, Lithobates pipiens, as well as a snake, Nerodia sipedon, vertebrate host, thus forming a sister taxon on its own within the larger first clade (represented in green). Such a result is not unanticipated as it is a well-known described three-host (snake, frog and mosquito Culex pipiens and Culex territans) life cycle [6,39]. Since $H$. ixoxo sp. nov. falls along with $H$. theileri, it may suggest that $H$. ixoxo sp. nov. follows a two-host life cycle such as that suggested for $H$. theileri in the latter's redescription by Netherlands et al. [6]. Furthermore, this small clade comprising $H$. ixoxo sp. nov. and $H$. theileri falls within the same monophyletic sub-clade containing $H$. catesbianae, $H$. clamatae and H. magna. Hepatozoon catesbianae and $H$. clamatae, and presumably $H$. magna [4] follow a two-host life-cycle which does not include a cystic stage within the intermediate vertebrate host and can be experimentally transmitted to culicine mosquito definitive hosts which subsequently demonstrate sporogonic stages as described by several authors $[4,5,39,40]$ (see Figure 3). Once again, the positions of the above Hepatozoon species including that of $H$. sipedon, supports the theory of Barta et al. [4] on the co-evolution of haemogregarines and their definitive hosts. Overall, the tree indicates with the phylogenetic placement of larger mammal hosts (clade 3), small rodent and snake hosts (clade 2) and frog, snake associations (clade 1), the potential of Hepatozoon host, prey and vector interactions.

\section{Conclusions}

Future research should include the identification of possible definitive hosts or vectors such as mosquitoes as well as experimental transmission studies. Considering the close morphological resemblance of all four species of Hepatozoon, the present study's $H$. ixoxo sp. nov. with $H$. aegyptia, $H$. magni and $H$. tunisiensis, it would be particularly beneficial to the study of Hepatozoon species of the Bufonidae if the latter three species could be isolated once more for molecular analysis. For instance, it can be seen that there is a small degree of intraspecies variation with regards to the size of the capped mature gamont of $H$. ixoxo sp. nov. between the three host species. The size of the gamont measured from A. garmani is significantly smaller than the gamonts from both $A$. gutturalis and $A$. maculatus. It may have been suggested in the past then, from a solely morphological point, that the Hepatozoon from A. garmani may be a different species. If intraspecific variation of sporogonic stages of a single species of Hepatozoon can occur between different vector individuals of the same host species [41], it is possible that this could also be true of the peripheral blood stages. The findings of this study strongly advocate the molecular analysis of those Hepatozoon species described in the past from A. regularis. This, it is believed will aid in determining with more accuracy whether or not they are all of the same species or if they are in fact different species, along with providing a better indication, with the use of their phylogenetic placement, of their possible vectors and life cycle dynamics. 


\section{Competing interests}

The authors declare that they have no competing interests.

\section{Authors' contributions}

All authors conceived and designed the project, participated in general data analysis and in drafting the manuscript. ECN and CAC carried out the field and lab work, prepared and examined blood smears, participated in the molecular genetic studies and in the sequence alignment. All authors read and approved the final manuscript.

\section{Acknowledgements}

We are most grateful to the late Prof. Angela J Davies Kingston, University, UK, for aiding in the identification of haemogregarine stages; to Kyle J McHugh, from North-West University (Potchefstroom campus) (NWU-P), for helping with the statistical analyses; to Dr. Donnavan JD Kruger, (NWU-P), for assistance with the GIS Map (Figure 1); as well as to Prof. Louis H Du Preez, (NWU-P), for assisting in sample collection, and comments on the draft manuscript. We would like to thank Ndumo Game Reserve and Kwa Nyamazane Conservancy, for allowing us to do field work and collect samples. In addition, we would like to thank Microbiology, Unit for Environmental Sciences, (NWU-P), for the use of their facilities. The financial assistance of the National Research Foundation (NRF) of South Africa to CAC (NRF Scarce Skills Postdoctoral Scholarship - Grant SFP13090332476) and to ECN (NRF Scarce Skills Masters Scholarship - Grant UID: 89924) are acknowledge. Opinions expressed and conclusions arrived at, are those of the authors and are not necessarily to be attributed to the NRF. The fieldwork and running expense of this work were funded by the Water Research Commission (WRC) of South Africa (Project K5-2185, NJ Smit, PI). Ezemvelo KZN Wildlife is thanked for research permits OP 674/2012, OP 5139/2012, OP 526/2014, and OP 839/2014.

Received: 15 August 2014 Accepted: 21 November 2014

Published online: 20 December 2014

\section{References}

1. Smith TG: The genus Hepatozoon (Apicomplexa: Adeleina). J Parasitol 1996, 82:565-585.

2. Davies AJ, Johnston MRL: The biology of some intraerythrocytic parasites of fishes, amphibians and reptiles. Adv Parasitol 2000, 45:1-107.

3. Telford SR: Hemoparasites of the Reptilia: Color Atlas and Text. New York: CRC Press; 2009

4. Barta JR, Ogedengbe JD, Martin DS, Smith TG: Phylogenetic position of the adeleorinid coccidia (Myzozoa, Apicomplexa, Coccidia, Eucoccidiorida, Adeleorina) inferred using 18S rDNA sequences. J Eukaryot Microbiol 2012, 59:171-180.

5. Desser SS, Hong H, Martin DS: The life history, ultrastructure, and experimental transmission of Hepatozoon catesbianae n. comb., an apicomplexan parasite of the bullfrog, Rana catesbeiana and the mosquito, Culex territans in Algonquin Park, Ontario. J Parasitol 1995, 81:212-222

6. Netherlands EC, Cook CA, Smit NJ, du Preez LH: Redescription and molecular diagnosis of Hepatozoon theileri (Laveran, 1905) (Apicomplexa: Adeleorina: Hepatozoidae), infecting Amietia quecketti (Anura: Pyxicephalidae). Folia Parasitol 2014, 61:293-300.

7. França C: Notes sur des hématozoaires de la Guinee Portugaise. Arch Inst Bact Cam Pest 1910, 3:229-238.

8. França C: Notes parasitologiques sur I'Angola. Ann Parasit Hum Comp 1925, 3:255-262.

9. Tuzet $\mathrm{O}, \mathrm{Grjebine} \mathrm{A:} \mathrm{Haemogregarina} \mathrm{lavieri} \mathrm{n.} \mathrm{sp.} \mathrm{Hémogrégarine}$ parasite du Bufo regularis Reuss. Soc Bioligie Montpellier 1957, 157:966-968.

10. Mohammed AHH, Mansour NS: Haemogregarina aegyptia sp. nov. from African toads (Bufo regularis) and its relationship to Haemogregarina tunisiensis Nicolle, 1904. Proc Zool Soc UAR 1963, 1:33-46.

11. Mohammed AHH, Mansour NS: Development of Haemogregarina boueti in the toad Bufo regularis. J Protozool 1966, 13:259-264.

12. Mansour NS, Mohammed AHH: Haemogregarina pestanae in the toad Bufo regularis. J Protozool 1966, 13:265-269.

13. Mansour NS, Mohammed AHH: Haemogregarina faiyumensis $\mathrm{n}$. sp. in the toad Bufo regularis in Egypt. J Protozool 1966, 13:269-271.

14. Younis SA, Saoud MFA: Haemogregarina aegyptia Mohammed and Mansour 1963; a blood parasite of Bufo regularis in the Sudan. Current Sci 1969, 38:435-436.
15. Abdel-Rahman AM, El-Naffar MK, Sakla AA, Khalifa R: On two species of Haemogregarine from Bufo regularis from Assiut Governorate, upper Egypt. J Egypt Soc Parasitol 1978, 8:43-51.

16. Hassan IM: On haemogregarine parasites of the toad Bufo regularis in Qena Governorate, upper Egypt with description of a new species. Haemogregarina magni. J Egypt Ger Soc Zool Inverteb Parasitol 1992, 9:379-385.

17. Nicolle MC: Sur une Hémogrégarine du Crapaud (Tunis.). C R Soc Biol 1904, 56:330-332.

18. Hoare CA: On some new haemogregarines from British East Africa. Parasitol 1920, 12:315-327.

19. ArcGIS $^{\circledR}$ software created by Esri [http://www.esri.com]

20. The IUCN Red List of Threatened Species. Conservation International \& NatureServe. 2004. Version 2014 [http://www.iucnredlist.org]

21. Frost DR, Grant T, Faivovich J, Bain RH, Haas A, Hadadd CFB, de Sá RO, Channing A, Wilkinson M, Donnellan SC, Raxworthy CJ, Campbell JA, Blotto BL, Moler PE, Drewes RC, Nussbaum RA, Lynch JD, Green DM, Wheeler WC: The amphibian tree of life. Bull Am Mus Nat Hist 2006, 297:1-370.

22. Du Preez L, Carruthers V: A Complete Guide to the Frogs of Southern Africa. Cape Town: Struik Nature; 2009

23. Cook CA, Smit NJ, Davies AJ: A redescription of Haemogregarina fitzsimonsi Dias, 1953 and some comments on Haemogregarina parvula Dias, 1953 (Adeleorina: Haemogregarinidae) from southern African tortoises (Cryptodira: Testudinidae), with new host data and distribution records. Folia Parasitol 2009, 56:173-179.

24. Ujvari B, Madsen T, Olsson M: High prevalence of Hepatozoon spp. (Apicomplexa: Hepatozoidae) infection in water pythons (Liasis fuscus) from tropical Australia. J Parasitol 2004, 90:670-672.

25. Mathew JS, Van Den Bussche RA, Ewing SA, Malayer JR, Latha BR, Panciera RJ: Phylogenetic relationships of Hepatozoon (Apicomplexa: Adeleorina) based on molecular, morphologic, and life-cycle characters. J Parasitol 2000, 86:366-372.

26. Geneious software created by Biomatters [http://www.geneious.com]

27. Basic Local Alignment Search Tool [http://blast.ncbi.nlm.nih.gov/Blast.cgi]

28. Edgar RC: MUSCLE: multiple sequence alignment with high accuracy and high throughput. Nucleic Acids Res 2004, 32:4673-4680.

29. Guindon S, Dufayard JF, Lefort V, Anisimova M, Hordijk W, Gascuel O: New algorithms and methods to estimate maximum-likelihood phylogenies: assessing the performance of PhyML 3.0. Syst Biol 2010, 59:307-321.

30. Posada D: jModelTest: Phylogenetic model averaging. Mol Biol Evol 2008, 2:1253-1256.

31. Huelsenbeck JP, Ronquist F: MrBayes: Bayesian inference of phylogenetic trees. Bioinformatics 2001, 17:754-755.

32. Široký P, Kamler M, Frye FL, Fictum P, Modrý D: Endogenous development of Hemolivia mauritanica (Apicomplexa: Adeleina: Haemogregarinidae) in the marginated tortoise Testudo marginata (Reptilia: Testudinidae): evidence from experimental infection. Folia Parasitol 2007, 54:13-18.

33. Cook CA, Lawton SP, Davies AJ, Smit NJ: Reassignment of the land tortoise haemogregarine Haemogregarina fitzsimonsi Dias 1953 (Adeleorina: Haemogregarinidae) to the genus Hepatozoon Miller 1908 (Adeleorina: Hepatozoidae) based on parasite morphology, life cycle and phylogenetic analysis of $18 \mathrm{~S}$ rDNA sequence fragments. Parasitol 2014, 2014(141):1611-1620.

34. Ball GH: Blood sporozoans from East African Amphibia. J Eukaryot Microbiol 1967, 14:521-527.

35. Boulianne B, Rodger CE, Todd GS: Phylogenetic analysis of Hepatozoon species (Apicomplexa: Adeleorina) infecting frogs of Nova Scotia, Canada, determined by ITS-1 sequences. J Parasitol 2007, 93:1435-1441.

36. Cook CA, Smit NJ, Davies AJ: First record of an intraleucocytic haemogregarine (Adeleorina: Haemogregarinidae) from South African tortoises of the species Stigmochelys pardalis (Cryptodira: Testudinidae). Afr Zool 2014, 49:290-294.

37. Telford SR, Wozniak EJ, Butler JF: Haemogregarine specificity in two communities of Florida snakes, with descriptions of six new species of Hepatozoon (Apicomplexa: Hepatozoidae) and a possible species of Haemogregarina (Apicomplexa: Haemogregarinidae). J Parasitol 2001, 87:890-905.

38. Harris DJ, Damas-Moreira I, Maia JPMC, Perera A: First report of Hepatozoon (Apicomplexa: Adeleorina) in caecilians, with description of a new species. J Parasitol 2014, 100:117-120. 
39. Smith TG, Desser SS, Martin DS: The development of Hepatozoon sipedon sp. nov. (Apicomplexa: Adeleina: Hepatozoidae) in its natural host, the northern water snake (Nerodia sipedon sipedon), in the culicine vectors Culex pipiens and C. territans, and in an intermediate host, the northern leopard frog (Rana pipiens). Parasitol Res 1994, 80:559-568.

40. Kim B, Smith TG, Desser SS: The life history and host specificity of Hepatozoon clamatae (Apicomplexa: Adeleorina) and ITS1 nucleotide sequence variation of Hepatozoon species of frogs and mosquitoes from Ontario. J Parasitol 1998, 84:789-797.

41. Paperna I, Lainson R: Ultrastructural studies on the sporogony of Hepatozoon spp. in Culex quinquefasciatus Say, 1823 fed on infected Caiman crocodilus and Boa constrictor from northern Brazil. Parasitology 2003, 127:147-154

\section{Submit your next manuscript to BioMed Central and take full advantage of:}

- Convenient online submission

- Thorough peer review

- No space constraints or color figure charges

- Immediate publication on acceptance

- Inclusion in PubMed, CAS, Scopus and Google Scholar

- Research which is freely available for redistribution 